\title{
Computer Aided Design / Computer Aided Manufacturing (CAD / CAM) Post and Core - A Review
}

\author{
Nor Faharina Abdul Hamid ${ }^{1}$, Nurul Jannah Zulkefle², \\ Tengku Fazrina Tengku Mohd Ariff3 ${ }^{3}$ Zuryati Ab Ghani ${ }^{4}$, Rohana Ahmad ${ }^{5}$ \\ 1,3,5 Centre of Restorative Studies, Universiti Teknologi MARA, Jalan Hospital 47000 Sungai Buloh, \\ Selangor, Malaysia. ${ }^{2}$ Universiti Teknologi MARA, Jalan Hospital 47000 Sungai Buloh, Selangor, Malaysia. \\ ${ }^{4}$ School of Dental Science, Universiti Sains Malaysia, Kubang Kerian 16150 Kelantan, Malaysia.
}

\section{ABSTRACT}

\section{BACKGROUND}

Nowadays, the use of computer aided design / computer aided manufacturing (CAD / CAM) in fabricating indirect restoration such as onlay, crown and bridge has increased tremendously. However, there is lack of clinical information and evidence on current material and fabrication techniques of CAD / CAM post and core. This paper describes the classification of the post and core system and review current perspectives on recent development of CAD / CAM post and core.

An electronic search of the literature was performed via PubMed and Scopus database, using the keyword (post and core) and (CAD / CAM) and (CAD / CAM post and core) as MeSH term. Articles eligible for inclusion in the present review were published in English, journal article and dated from January 2000 until November 2020.

A total of 31 publications consisting of 18 in-vitro studies, 7 case reports, 4 finite element analysis and 2 clinical techniques were included in this review. Analysis parameters included are options of chairside CAD / CAM materials, CAD / CAM system and milling machine used, advantages and disadvantages and future direction of CAD / CAM post and core. CAD /CAM post and core can be alternative option as compared to the custom-made post and core and prefabricated post and core.

\section{KEY WORDS}

Computer - Aided Design, Computer - Aided Manufacturing, Dental Material, Indirect Restoration, Post and Core
Corresponding Author: Dr. Nor Faharina Abdul Hamid, Centre of Restorative Studies, Faculty of Dentistry,

Universiti Teknologi MARA, 47000 Sungai Buloh Campus, Selangor, Malaysia.

E-mail: faharina@uitm.edu.my

DOI: $10.14260 /$ jemds/2021/640

How to Cite This Article: Hamid NFA, Zulkefle NJ, Ariff TFTM, et al. Computer aided design/computer aided manufacturing (CAD / CAM) post and core - a review. J Evolution Med Dent Sci 2021;10(36):3143-3151, $10.14260 /$ jemds/2021/640

Submission 03-12-2020,

Peer Review 18-08-2021, Acceptance 26-08-2021,

Published 06-09-2021.

Copyright (C) 2021 Nor Faharina Abdul Hamid et al. This is an open access article distributed under Creative Commons Attribution License [Attribution 4.0 International (CC BY 4.0)] 


\section{BACKGROUND}

Topics on restoration of endodontically treated teeth always remains controversial in numerous perspectives. It is commonly associated with issues of restoring pulp less teeth with or without post. The placement of post has been regarded as a technique for reinforcing a pulp less tooth ages ago, however recent study has shown that unnecessary placement of post may weaken the tooth rather than reinforcing it. ${ }^{1}$ The main purpose of a post is to retain a core. Placement of post is required when there is extensive loss of coronal tooth structure following endodontic treatment, prior to definitive restorative treatment. However, it is important to note that not all endodontic cases need a post.2,3 Justification of the need of post and core and selection of the appropriate post and core system is based on clinical judgement. Procedural errors can occur during post space preparation or during post placement which can increase the possibility of treatment failure.

\section{Ideal Characteristic of Post}

The ideal post system should provide core retention without creating undesirable stresses in remaining tooth structure. ${ }^{4} \mathrm{~A}$ post should have high tensile strength, high fatigue resistance to occlusal and shear loading and must be able to distribute force to the affecting tooth. ${ }^{5}$ Other fundamental requirements include biocompatibility, precise and harmless electro chemical activity. ${ }^{6}$ Besides, it is recommended that post length must be at least equivalent to the crown height or two-third of the root length to help in stress distribution and to provide resistance to occlusal forces ${ }^{7}$ or aesthetically challenging case especially when involving anterior teeth, it is valuable to have post that has similar or comparable optical properties as natural teeth. ${ }^{5}$

\section{Classification of Post and Core}

There are many classifications of post. Figure 1 illustrates the classification of post and core but for this paper, it will be discussed by material composition and are subdivided as custom made post and prefabricated post (Fig. 1).

\section{Custom Made Post and Core}

Custom-made cast posts and cores are indicated when there is extensive loss of tooth structure. It is also indicated for wide, non-circular, oval or extremely tapered canal where the cylindrical prefabricated posts may not achieve intimate and adequate adaptation of the post to the canal which can compromise the retention of the post. ${ }^{8-10}$ The cast gold post and core has been considered the gold standard due to its excellent success rate, favourable long-term prognosis, superior mechanical strength and ease of fabrication. ${ }^{11-14}$ Other options available for custom made post and core are cobalt-chromium (Co-Cr) or Nickel-chromium (Ni-Cr). Although $\mathrm{Ni}-\mathrm{Cr}$ is one of the cheaper option when compared to gold, a previous study showed that $\mathrm{Ni}-\mathrm{Cr}$ posts were associated with highest stress values within dentin especially in post-dentin interface area as it is stiffer when compared to teeth. ${ }^{15}$ Nevertheless, one study claimed that $\mathrm{Ni}$-Cr produced less bending of post and core under load with better stress distribution to the root with acceptable clinical longevity. ${ }^{16}$ Hypothetically, metal custom made post and core are more conservative to tooth structure since it is designed to conform with the shape of root canal as well as to provide maximum retention of coronal restoration. ${ }^{11}$ However, although it can be tailored to various shapes of the root canal, the drawback is mainly due to significant difference in modulus of elasticity between metal alloys and dentine which create nonhomogenous stress in root dentine and around the post which results in separation of the post. This can cause catastrophic root fracture due to excessive functional stress concentration around the post. ${ }^{13,17}$ Another drawback of custom-made metal post is that it may create discoloration and a blue-grey effect in case of thin bone and thin gingival tissue. In addition, with several translucent ceramic crown systems available now, there is concern on how the shade of the post and core as abutment affects the definitive shade of the final restoration. A recent study has shown that the underlying core colour may affect the definitive result for a ceramic crown with high translucency and when the crown thickness is of less than 1.6 mm. ${ }^{6}$

\section{Prefabricated Post and Core}

Other alternative to custom made metal post and core is prefabricated post and core. The use of prefabricated post requires custom made build-ups with amalgam or composite resin. It is indicated for tooth with round shaped canals and adequate bulk of the dentinal walls, where the post can have intimate adaptation to the prepared canal. Prefabricated posts are available in different materials such as metal, composite resin or ceramic. The development of tooth-coloured posts has improved the aesthetics of teeth restored with posts and cores. ${ }^{18}$ Prefabricated post and core requires preparation of the root canal to the size and shape of the post. ${ }^{8}$ However, it does not take into consideration the individual shape of the root canal, thus the adaptation is not always ideal. It requires more dentin removal while preparing the tooth, thus it can compromise fracture resistance as well as retention of the post. Small, tapered roots, such as maxillary lateral incisors or mandibular incisors may be weakened if prepared to fit the post. In addition, when the prefabricated post and core are made from two separate entities, the flexion of the post under functional forces may influence the post-core interface which can result in separation of the core and permanent deformation of post. Nevertheless, the prefabricated posts with core restorations can simplify restorative procedures, decrease chair time, while achieving clinical success.6,19 Recently, there is an alternative approach apart from prefabricated post systems and conventional custom-made metal posts and cores. The advance of the computer-aided design / computer-aided manufacturing (CAD / CAM) technology in the field of dentistry has brought innovative solution in fabricating the post and core. Therefore, the purpose of this review is to provide an overview of CAD / CAM post and core in the current literature.

\section{METHODS}

An electronic search of literature was performed via PubMed database, using the keyword (post and core) AND (CAD /CAM) AND (CAD /CAM post and core) as MeSH term. A total of 160 titles from PubMed and 131 titles from Scopus were identified. Articles eligible for inclusion in the present review were 
published in English, journal article and dated from January 2000 until November 2020. Figure 2 shows the review identification and screening process. The titles and abstract of all papers were carefully appraised to remove duplicate articles and articles that were outside the scope of this review. The papers were excluded if their main focus was on CAD/ CAM endocrown, crown, implant, veneer, not used milling machine as type of manufacturing or if they did not include CAD / CAM post and core. If the focus of the paper could not be determined accurately from the title or abstract, the full text article was studied. Additionally, any relevant dental journals from website were explored in the search for in press papers.

\section{RESULTS}

\section{Overview on Current Perspectives, Recent Development and Research of CAD / CAM Post and Core}

Following review identification and screening process, 34 articles were retained, and the full article was identified. After further reading, three articles were excluded leaving a total of 31 publications which consist of 18 in vitro studies, 7 case reports, 3 finite element analysis and 2 clinical techniques.

\begin{tabular}{|c|c|c|c|c|c|c|}
\hline $\begin{array}{l}\text { Sl. } \\
\text { No. }\end{array}$ & $\begin{array}{l}\text { Author } \\
\text { (Year) }\end{array}$ & Title & Type & $\begin{array}{l}\text { CAD / CAM } \\
\text { System }\end{array}$ & $\begin{array}{l}\text { CAD / CAM } \\
\text { Materials }\end{array}$ & $\begin{array}{c}\text { Data and/or } \\
\text { Comments from Author }\end{array}$ \\
\hline 1 & $\begin{array}{l}\text { Perucellietal. } \\
\quad 2020.20\end{array}$ & $\begin{array}{l}\text { Effect of half-digital workflows on } \\
\text { the adaptation of customized CAD } \\
\text { - CAM compositepost and cores }\end{array}$ & In-vitro & $\begin{array}{l}\text { Scanner: Ceramill Map 400; Amann Girrbach } \\
\text { AG Milling machine: Ceramill Motion 2; } \\
\text { Amann Girrbach AG) }\end{array}$ & BravaBlock; FGM & $\begin{array}{l}\text { Adaptation of metal post and cores is superior compared to CAD - } \\
\text { CAM composite resin post and cores. However, CAD - CAM } \\
\text { composite resin post and cores had clinically acceptablerange in } \\
\text { terms of adaptation. }\end{array}$ \\
\hline 2 & $\begin{array}{l}\text { Farah, Aloraini etal. } \\
2020.21\end{array}$ & $\begin{array}{l}\text { Fabrication of custom post-and } \\
\text { l. coreusing a directly fabricated } \\
\text { silicone pattern and digital } \\
\text { workflow }\end{array}$ & $\begin{array}{l}\text { Clinical } \\
\text { techniques }\end{array}$ & $\begin{array}{l}\text { Scanner: Artica Autoscan;KaVo Germany } \\
\text { Milling machine: inLab MCX5; Dentsply } \\
\text { Sirona Inc;; York, PA. }\end{array}$ & $\begin{array}{l}\text { CAD / CAM wax disc author suggested } \\
\text { thatany CAD / CAM material can be used } \\
\text { depending on clinical need and material } \\
\text { availability. }\end{array}$ & $\begin{array}{l}\text { Thisreportpresents a technique for construction of CAD / CAM } \\
\text { post and core using polyvinyl siloxane(PVS) ocdusal registration } \\
\text { material, followed by a digital workflow. }\end{array}$ \\
\hline 3 & $\begin{array}{l}\text { Libonati, Di Taranto } \\
\text { et al. } 2020^{22}\end{array}$ & $\begin{array}{l}\text { CAD / CAM customized glass fiber } \\
\text { postand corewith digital intraoral } \\
\text { impression: acase report }\end{array}$ & Case report & $\begin{array}{l}\text { Scanner:Trios, 3shapeintraoral scanner } \\
\text { t Milling machine: Roland DWX-50, Irvine, CA, } \\
\text { USA }\end{array}$ & Trilor (Bioloren, Saronno,Italy) & $\begin{array}{c}\text { The author prepared thepost space up to } 9 \mathrm{~mm} \text { in depth prior } \\
\text { scanning using the intraoral digital scanner (Trios,3Shape). He also } \\
\text { suggested that dueto nature and geometry of the post and core, } \\
\text { slower and low stress milling machine was used to reduce error } \\
\text { and vibrations. }\end{array}$ \\
\hline 4 & $\begin{array}{l}\text { Pang, Fengetal. } \\
\quad 2019^{10}\end{array}$ & $\begin{array}{l}\text { Fracture behaviours of maxillary } \\
\text { central incisors with flared root } \\
\text { canalsrestored with CAD/CAM } \\
\text { integrated glass fiber post and } \\
\text { core }\end{array}$ & In-vitro & $\begin{array}{l}\text { Scanner: BlueCam scanner (inEos } \\
\text { Blue,SironaDental Systems, Germany) } \\
\text { Milling machine: DeRTeDT- 500, DeRTe } \\
\text { (DLT (Guangzhou, China) }\end{array}$ & $\begin{array}{l}\text { Experimental CAD / CAMintegrated } \\
\text { glass fiber post and core system (OYA } \\
\text { Ricom New Material Sci. \& Tech. Beijing, } \\
\text { China) }\end{array}$ & $\begin{array}{c}\text { The author concluded that CAD / CAM integrated glass fiber post } \\
\text { and corerestoration significantly improves the fractureresistance } \\
\text { as compared to prefabricated fiber post and cast gold alloy post. } \\
\text { Composition of experimental CAD / CAM block: "a new typeof } \\
\text { epoxy matrixglass fiber resin block made by pultrusion moulding, } \\
\text { containing } 62 \% \text { volume fiber component and highly crosslinked } \\
\text { polymer molecules" }\end{array}$ \\
\hline 5 & $\begin{array}{l}\text { de Andrade, João- } \\
\text { Paulo-Mendes } \\
\text { Tribst etal. } 2019^{23}\end{array}$ & $\begin{array}{l}\text { A study on stress distribution to } \\
\text { cement layer and rootdentin for } \\
\text { post and cores made of CAD } \\
\text { /CAM materialswith different } \\
\text { elasticity modulusin the absence } \\
\text { of ferrule }\end{array}$ & $\begin{array}{l}\text { Finite } \\
\text { element } \\
\text { analysis }\end{array}$ & NA & $\begin{array}{c}\text { Nanoceramic resin (Lava Ultimate, 3M } \\
\text { ESPE, USA) Composite resin (Paradigm } \\
\text { MZ10,3M ESPE, USA) Hybrid ceramic } \\
\text { (Enamic, VITA Zahnfabrik, Germany } \\
\text { Lithium disilicate (e- maxCAD, Ivodar } \\
\text { Vivadent) Titanium (Ti-Al6-V4) and } \\
\text { tetragonal zirconia polycrystalline } \\
\text { stabilized byyttria (Y -TZP, VITA Zahn } \\
\text { Fabrik) }\end{array}$ & $\begin{array}{l}\text { This study involves postand cores made of sixdifferentCAD / CAM } \\
\text { materials. Stress distribution in dentin was similar for all group } \\
\text { regardless of post and corematerial. However, stressconcentration } \\
\text { in the cement line between post and dentin were slightly higher in } \\
\text { zirconia post and core. }\end{array}$ \\
\hline 6. & $\begin{array}{l}\text { Eid, Koken et al. } \\
2019^{24}\end{array}$ & $\begin{array}{l}\text { Effect of fabrication technique and } \\
\text { thermal cycing on thebond } \\
\text { strength of CAD / CAM milled } \\
\text { custom fit anatomical post and } \\
\text { cores: an in vitro study. }\end{array}$ & In vitro & $\begin{array}{l}\text { Scanner: Ceramill Map ( } 400^{c} \text { ) Milling } \\
\text { Machine: Motion } 2^{c} \text { mill }\end{array}$ & $\begin{array}{l}\text { Trilor (Bioloren, Saronno, Italy) } \\
\text { Ambarino (Creamed, MarburgGermany) }\end{array}$ & $\begin{array}{l}\text { This study used computerized microtomography (microCT) to } \\
\text { investigate the voids and to determine the cement thickness } \\
\text { between prefabricated and CAD / CAM post and core. The authors } \\
\text { concluded thatcement thickness was thinner with increased } \\
\text { retention noted at CAD / CAM posts and cores. }\end{array}$ \\
\hline 7. & $\begin{array}{l}\text { Eid, Azzametal. } \\
\qquad 2019^{25}\end{array}$ & $\begin{array}{l}\text { Influence of adaptation and } \\
\text { adhesion on theretention of } \\
\text { computer- aided design / } \\
\text { computer - aided manufacturing } \\
\text { glass fiber poststo root canal }\end{array}$ & In vitro & $\begin{array}{l}\text { Scannar: Imetric 1041, Imetric 3D, } \\
\text { Courtenay, Switzerland Milling machine: D5, } \\
\text { Datron, Darmstadt, Germany }\end{array}$ & Trilor (Bioloren, Saronno,Italy) & $\begin{array}{l}\text { The authors conduded that the use of customized CAD / CAM fiber } \\
\text { reinforced composite postsh have apositive effect on thebond } \\
\text { strength to root canal walls in comparison to prefabricated fiber } \\
\text { posts. }\end{array}$ \\
\hline 8. & $\begin{array}{l}\text { Alkhatri, Saleh etal. } \\
\qquad 2019^{26}\end{array}$ & $\begin{array}{l}\text { Evaluating facture resistance and } \\
\text { failure modes of root filled teeth } \\
\text { restored with CAD / CAM - } \\
\text { Fabricated post and core }\end{array}$ & In vitro & $\begin{array}{l}\text { Scanner:3D Ceramill Map } 300 \text { scanner } \\
\text { (Amann Girrbach AG) Milling machine: } \\
\text { *Ceramill Motion 2 (Amann Girrbach AG) }^{\text {"Galaxy BioMill, (Biolase, USA) }}\end{array}$ & 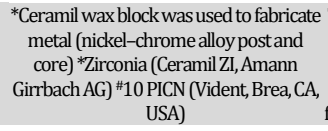 & $\begin{array}{l}\text { e This study used different milling machines for different CAD /CAM } \\
\text { block Ceramil wax blockand zirconiawere milled using Ceramill } \\
\text { Motion } 2 \text { while } 10 \text { PICN was milled using Galaxy BioMill. The } \\
\text { authors conduded that there was no significant difference in the } \\
\text { fracture resistance between metal, zirconiaand PINC post and core. }\end{array}$ \\
\hline 9. & $\begin{array}{l}\text { Oguz,Egilmezetal. } \\
2019^{27}\end{array}$ & $\begin{array}{l}\text { Surfacetreatmenteffects on bond } \\
\text { strength of CAD/CAM fabricated } \\
\text { posts to root canal dentin }\end{array}$ & In vitro & $\begin{array}{c}\text { Scanner: BlueCam scanner (inEos Blue, } \\
\text { Sirona Dental Systems, Germany) Milling } \\
\text { machine: inLab MCXL, Dentsply Sirona Inc; } \\
\text { York,PA }\end{array}$ & $\begin{array}{l}\text { Cerasmart (GC America) Enamic, VITA } \\
\text { Zahnfabrik, Germany) Lava Ultimate,3M } \\
\text { Germany). }\end{array}$ & $\begin{array}{l}\text { Micro push-out bond strength of poststo dentin was significantly } \\
\text { affected by the typeof postmaterial but notby the surface } \\
\text { treatment such aslaser, hydrofluoric acid or sandblasting. }\end{array}$ \\
\hline 10. & $\begin{array}{l}\text { Eid, Juloski etal. } \\
2019^{28}\end{array}$ & $\begin{array}{l}\text { Fracture resistance and failure } \\
\text { pattern of endodontically treated } \\
\text { teeth restored with computer- } \\
\text { aided design / computer-aided } \\
\text { manufacturing postand cores: A } \\
\text { PilotStudy }\end{array}$ & In vitro & $\begin{array}{l}\text { Scanner: Imetric 1041, Courtenay, } \\
\text { Switzerland Milling Machine: Datron D5, } \\
\text { Datron AG, Darmstadt, Germany). }\end{array}$ & $\begin{array}{l}\text { Trilor, Bioloren (AMC,Italy) Ambarino® } \\
\text { High Class (Germany) }\end{array}$ & $\begin{array}{l}\text { All systems evaluated (prefabricated fiber post and one-pieces } \\
\text { milled CAD / CAM postand core) offered adequate mean load to } \\
\text { failure valuesfor restoration of endodontically treated tooth. } \\
\text { However, one-pieces high-density polymer CAD / CAM post and } \\
\text { cores showed better performance than prefabricated fiber posts. }\end{array}$ \\
\hline 11. & $\begin{array}{l}\text { Borzangy,Saker et } \\
\text { al. } 2019^{29}\end{array}$ & $\begin{array}{l}\text { Effect of restoration technique on } \\
\text { resistance to fracture of } \\
\text { endodontically treated anterior } \\
\text { teeth with flared root canals }\end{array}$ & In vitro & $\begin{array}{l}\text { Scanner: Ceramill map400, (Amann } \\
\text { Girrbach) Milling machine: Ceramill Motion } 2 \\
\text { 5X,AmannGirrbach) }\end{array}$ & 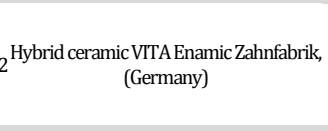 & $\begin{array}{l}\text { This study tested fiber reinforced compositeresin, cast post and } \\
\text { core, CAD / CAM polymer-infiltered ceramic post and core in wide } \\
\text { root canal. They conduded thatone-piece CAM / CAM post and } \\
\text { core can be an alternative either glass fiber post relined with } \\
\text { compositeresin. }\end{array}$ \\
\hline 12. & $\begin{array}{l}\text { Moustapha, } \\
\text { AlShwaimietal. } \\
2019^{30}\end{array}$ & $\begin{array}{l}\text { Marginal and internal fit of CAD/ } \\
\text { CAM fiber post and cores }\end{array}$ & In vitro & $\begin{array}{l}\text { Scanner: Intraoral scanner: Trios, 3shape) } \\
\text { Laboratory scanner: Imetric 1041, } \\
\text { Courtenay, Switzerland Milling machine: } \\
\text { Datron D5, Datron, Germany }\end{array}$ & Trilor, Bioloren (AMC, Italy) & $\begin{array}{l}\text { The study concluded thatdirect digitalization using Trios } 3 \text { showed } \\
\text { better adaptation when compared to indirect digitalization. For } \\
\text { future research, theauthor suggeststo investigate the pre and post } \\
\text { cementation cement thickness in relation to post and core. }\end{array}$ \\
\hline 13. & $\begin{array}{l}\text { Spina, da Costaetal. } \\
2018^{31}\end{array}$ & $\begin{array}{l}\text { Scanning of root canal impression } \\
\text { for thefabrication of aresin CAD- } \\
\text { CAM-customized postand core }\end{array}$ & $\begin{array}{l}\text { Digital } \\
\text { workflow } \\
\text { technique/ } \\
\text { Case report }\end{array}$ & $\begin{array}{l}\text { Scanner: Ceramill Map400; Amann Girrbach } \\
\text { AG Milling machine: Ceramill Motion 2; } \\
\text { Amann Girrbach AG }\end{array}$ & $\begin{array}{l}\text { Lava Ultimate } \\
\text { (3M, Germany) }\end{array}$ & $\begin{array}{l}\text { This case reportdescribes dinical technique using direct polyvinyl } \\
\text { siloxane impression to fabricate post and core. }\end{array}$ \\
\hline 14. & $\begin{array}{l}\text { Tsintsadze, Juloski } \\
\text { etal. } 2018^{32}\end{array}$ & $\begin{array}{l}\text { Effects of scanning technique on in } \\
\text { vitro performance of CAD /CAM - } \\
\text { fabricated fiber posts }\end{array}$ & In vitro & $\begin{array}{l}\text { Scanner: inEos scanner (Sirona, Bensheim, } \\
\text { Germany). Milling machine: inLab MCXL } \\
\text { CAD/CAM milling unit (Sirona) }\end{array}$ & $\begin{array}{l}\text { Experimental fiber - reinforced } \\
\text { composite blocks (RTD, France) }\end{array}$ & $\begin{array}{l}\text { Scanning of postand core space was done either using direct } \\
\text { scanning of thepostspace (DS), scanning of a polyether impression } \\
\text { of the post space(IS) or scanning of a plaster model of the post } \\
\text { space (MS). They conduded thatpost retention was better for posts } \\
\text { fabricated by DS technique while cement thickness was thicker in } \\
\text { the MS group compare to DS and IS. }\end{array}$ \\
\hline 15. & $\begin{array}{l}\text { Garcia,da Costa et } \\
\mathrm{al}^{33}\end{array}$ & $\begin{array}{l}\text { Effect of surface treatments on the } \\
\text { bond strength of CAD /CAM } \\
\text { fiberglass posts }\end{array}$ & In-vitro & $\begin{array}{l}\text { Scanner: Ceramill Scannermap400, Austria } \\
\text { Milling machine: Ceramill Motion 2, Austria }\end{array}$ & $\begin{array}{l}\text { Experimental block of glass fiber and } \\
\text { epoxy resin }\end{array}$ & $\begin{array}{l}\text { Different surfacetreatments (using ethanol, hydrogen peroxide, } \\
\text { ethanol and silane and hydrogen peroxide and silane did not } \\
\text { interfere in bond strength on experimental CAD / CAM block. }\end{array}$ \\
\hline 16. & $\begin{array}{l}\text { da Costa, Freire et } \\
\text { al. } 2017^{34}\end{array}$ & $\begin{array}{l}\text { Effect of CAD / CAM glass fiber } \\
\text { post-coreon cement } \\
\text { micromorphology and fracture } \\
\text { resistanceof endodontically } \\
\text { treated roots }\end{array}$ & In vitro & $\begin{array}{l}\text { Scanner:Ceramill Map 400; Amann Girrbach } \\
\text { AG Milling machine: Ceramill Motion 2; } \\
\text { Amann Girrbach AG }\end{array}$ & $\begin{array}{l}\text { Experimental block CAM/CAM } \\
\text { customized glass-fiber reinforced }\end{array}$ & $\begin{array}{l}\text { Experimental CAD / CAM glass fiber post and core helpsin reducing } \\
\text { void and cement film thickness and doesnot affect the fracture } \\
\text { strength of flared root canalsor causes catastrophic failure ofthe } \\
\text { root }\end{array}$ \\
\hline
\end{tabular}

J Evolution Med Dent Sci / eISSN - 2278-4802, pISSN - 2278-4748 / Vol. 10 / Issue 36 / Sept. 06, 2021 


\begin{tabular}{|c|c|c|c|c|c|c|}
\hline 17. & $\begin{array}{l}\text { Gonzaga and } \\
\text { Correr, } 2017^{35}\end{array}$ & $\begin{array}{l}\text { CAD/CAM post and coreusing } \\
\text { different aestheticmaterials: } \\
\text { Fracture resistance and bond } \\
\text { strengths }\end{array}$ & In-vitro & $\begin{array}{l}\text { Scanner: Ceramill Map 400d Milling Machine: } \\
\text { Motion 2d; Amann Girrbach AG }\end{array}$ & $\begin{array}{l}\text { VITAEnamic, Zahnfabrik, (Germany) } \\
\text { Lava Ultimate(3M, Germany) } \\
\text { Experimental epoxy fiberreinforced } \\
\text { block CAM / CAM }\end{array}$ & $\begin{array}{l}\text { All three CAD / CAM materials offer excellent adaptation, good } \\
\text { aesthetic with good optical properties, good performance in relative } \\
\text { to fracture resistance to beused as alternative material of post and } \\
\text { core. }\end{array}$ \\
\hline 18. & $\begin{array}{l}\text { Tsintsadze, Juloski } \\
\text { etal. } 2017^{36}\end{array}$ & $\begin{array}{l}\text { Performance of CAD / CAM } \\
\text { fabricated fiber posts in oval- } \\
\text { shaped root canals: An in vitro } \\
\text { study }\end{array}$ & In vitro & $\begin{array}{l}\text { Scanner: inEos } 4.2 \text { scanner (Denstply, Sirona) } \\
\text { Milling Machine: inLab MCXL (Dentsply, } \\
\text { Sirona) }\end{array}$ & Experimental CAD / CAM fiber blocks & $\begin{array}{l}\text { The authors conduded that CAD / CAM - fabricated fiber posts } \\
\text { achieved significantly higher retention than prefabricated fiber } \\
\text { posts and comparable to cast metal posts. The cementlayer } \\
\text { thickness of CAD / CAM was lower than prefabricated fiber post but } \\
\text { higher than that around castmetal posts. No differences on nano } \\
\text { leakage between CAD / CAM fabricated and prefabricated fiber } \\
\text { posts, but significantly lower in cast metal posts }\end{array}$ \\
\hline 19. & $\begin{array}{l}\text { Bilgin, Erdem et al. } \\
2016^{37}\end{array}$ & $\begin{array}{c}\text { Comparison of fracture resistance } \\
\text { between cast, CAD / CAM milling, } \\
\text { and direct metal laser sintering } \\
\text { metal post systems }\end{array}$ & In vitro & $\begin{array}{l}\text { Scanner: D810, 3Shape A/S, Copenhagen, } \\
\text { Denmark Milling machine: HSC } 20 \text { linear, } \\
\text { DMG, Germany }\end{array}$ & $\begin{array}{l}\text { Co-Cr block (Coprabond K, WhitePeaks, } \\
\text { Germany) }\end{array}$ & $\begin{array}{l}\text { This study was to compare the fracture resistance of Co-Crpost and } \\
\text { cores fabricated with 3 different techniques: traditional casting (TC) } \\
\text { CAD / CAM milling (CCM) and direct metal laser sintering (DMLS). } \\
\text { The authors conduded thatposts fabricated by CCM displayed } \\
\text { higher fracture resistance while posts fabricated by TC and DMLS } \\
\text { performed similarly in terms of fracture resistance. }\end{array}$ \\
\hline 20. & $\begin{array}{l}\text { Gülnahar,Soygun et } \\
\text { al.2016 }\end{array}$ & $\begin{array}{l}\text { Thecustomized forming of the } \\
\text { applied post-core system: Case } \\
\text { reports }\end{array}$ & Case report & $\begin{array}{l}\text { Scanner and milling machine: Dental Wings, } \\
\text { Montreal, Canada }\end{array}$ & Zirconia block (Zirkonzahn, Switzerland) & $\begin{array}{l}\text { This case series illustrated the fabrication of one endocrown and } \\
\text { onezirconia post and core even though the current available CAD / } \\
\text { CAM systems are not programmed for fabrication of post and core } \\
\text { restorations. }\end{array}$ \\
\hline 21 & $\begin{array}{l}\text { Kalyoncuoğlu, Ural } \\
\quad \text { etal. } 2015^{39}\end{array}$ & $\begin{array}{l}\text { Effect of 1-piece post and core } \\
\text { fabrication techniques on fracture } \\
\text { strength }\end{array}$ & In-vitro & $\begin{array}{l}\text { Scanner and milling machine: CEREC3, } \\
\text { Sirona, Germany }\end{array}$ & Zirconium oxidepost-core & $\begin{array}{l}\text { This study evaluated and compared the fracture strengths of post } \\
\text { and coreproduced with different fabrication techniques; lost-wax } \\
\text { technique and CAM/ CAM, lasersintered for metal and CAM / CAM } \\
\text { for zirconia. The authors concluded that zirconia posts and cores } \\
\text { showed highest fracture resistance and can be an alternative to the } \\
\text { custom-made1-piece post and core technique. }\end{array}$ \\
\hline 22. & $\begin{array}{l}\text { Chen, Fengetal. } \\
\qquad 2015^{40}\end{array}$ & $\begin{array}{l}\text { Finite element analysis of stress } \\
\text { distribution in four different } \\
\text { endodontic post systems in a } \\
\text { model canine }\end{array}$ & $\begin{array}{l}\text { Finite } \\
\text { element } \\
\text { analysis }\end{array}$ & NA & $\begin{array}{l}\text { CAD / CAM zirconia CAD / CAM glass } \\
\text { fiber }\end{array}$ & $\begin{array}{l}\text { This study investigates the stress distribution in a maxillary canine } \\
\text { restored with four different types of post systems which are: } \mathrm{CAD} \text { / } \\
\text { CAM zirconia: CAD / CAM glass fiber, cast titanium and cast gold at } \\
\text { different levels of alveolar boneloss. The authors concluded that } \\
\text { CAD / CAM zirconiapost system is the best options asitproduced } \\
\text { the lowest maximum von Mises stress in the dentin layer as } \\
\text { compared to glass fiber post. }\end{array}$ \\
\hline 23. & $\begin{array}{l}\text { Chen, Fenget al. } \\
\quad 2015^{41}\end{array}$ & $\begin{array}{l}\text { Finite element analysisto study } \\
\text { the effectsof using CAD / CAM } \\
\text { glass-fiber post system ina } \\
\text { severely damaged anterior tooth }\end{array}$ & $\begin{array}{l}\text { Finite } \\
\text { element } \\
\text { analysis }\end{array}$ & NA & CAD / CAM glass fiber & $\begin{array}{c}\text { The study concludes thatmaximal von Mises stress was } \\
\text { significantly affected by bone level, rather than by dentin thickness. } \\
\text { It also suggested that CAD / CAM glass fiber post system may be an } \\
\text { alternative treatmentfor a severely damaged anterior tooth with } \\
2 / 3 \text { of bone level. }\end{array}$ \\
\hline 24. & Chenetal.2014 42 & $\begin{array}{l}\text { A novel computer-aided method } \\
\text { to fabricate a custom one-piece } \\
\text { glass fiber dowel and core based } \\
\text { on digitized impression and } \\
\text { crown preparation data }\end{array}$ & Case report & $\begin{array}{l}\text { Scanner: Activity 102; Smart Optics, Bochum, } \\
\text { Germany Milling machine: HSC } 20 \text { linear, } \\
\text { DMG, Seebach, Germany }\end{array}$ & $\begin{array}{l}\text {, Glass fiber blocks (Ouyaruikang Co., Ltd, } \\
\text { Beijing, China) }\end{array}$ & $\begin{array}{l}\text { This paper discusses on novel technique in fabrication of post and } \\
\text { core using } 107 \text { dowel impression scanning and dinical standard } \\
\text { crown preparation data. The authors also reported two successful } \\
\text { clinical cases using this newtechnique suggesting that itis effective } \\
\text { and practical method to adopt. }\end{array}$ \\
\hline 25. & $\begin{array}{l}\text { Ozcan and Sahin } \\
2013^{43}\end{array}$ & $\begin{array}{l}\text { In vitro evaluation of the fracture } \\
\text { strength of all-ceramic core } \\
\text { materials on zirconium posts }\end{array}$ & In vitro & $\begin{array}{l}\text { Scanner: Cerec 3D in Eos Milling Machine: } \\
\text { Cerec 3DCAD / CAM system }\end{array}$ & $\begin{array}{l}\text { Zirconium blocks (InCoris Sirona } \\
\text { Germany) }\end{array}$ & $\begin{array}{l}\text { This study conduded that one-piece zirconium post-core systems } \\
\text { have zero mechanical advantages over core constructed separately } \\
\text { and adhesively, luted to post and tooth. }\end{array}$ \\
\hline 26. & $\begin{array}{l}\text { Yousif Marghalani, } \\
\text { Tharwat Hamed et } \\
\text { al. } 2012^{44}\end{array}$ & $\begin{array}{c}\text { Three-dimensional finite element } \\
\text { analysis of custom- madeceramic } \\
\text { dowel made using CAD / CAM } \\
\text { technology }\end{array}$ & $\begin{array}{l}\text { Finite } \\
\text { element } \\
\text { analysis }\end{array}$ & NA & $\begin{array}{l}\text { Zirconia block (Cercon, DeguDent, Hanau } \\
\text {-Germany), }\end{array}$ & $\begin{array}{l}\text { FES show no significant differences in the maximum stresses in } \\
\text { umost regions and it indicated that stress distribution in the rootwas } \\
\text { comparable for zirconia and gold. They concluded that zirconia can } \\
\text { be of great alternative to replaceexpensive gold as post and core. }\end{array}$ \\
\hline 27. & $\begin{array}{l}\text { Kumar and Patil } \\
2012^{45}\end{array}$ & $\begin{array}{l}\text { Forced orthodontic extrusion and } \\
\text { useof CAD / CAM for } \\
\text { reconstruction of grossly } \\
\text { destructed crown: A } \\
\text { multidisciplinary approach }\end{array}$ & Case report & $\begin{array}{l}\text { Scanner and milling machine: Amann } \\
\text { Girrbach, Germany }\end{array}$ & $\begin{array}{l}\text { Zirconia block (Amann Girrbach, } \\
\text { Germany) }\end{array}$ & $\begin{array}{l}\text { The case series describe theuse of indirect technique using } \\
\text { impression of the post space and pattern resin (GCAmerica) for } \\
\text { designing CAD / CAM post and core. Cased escription: They } \\
\text { emphasize to remove undercutduring postspace preparation }\end{array}$ \\
\hline 28. & $\begin{array}{l}\text { Sipahi, Toksoyet al. } \\
2011^{46}\end{array}$ & $\begin{array}{l}\text { Effect of physical and } \\
\text { physicochemical surface } \\
\text { treatment methodson the tensile } \\
\text { strength of CAD / CAM-fabricated } \\
\text { zirconia posts and cores luted to } \\
\text { root canals }\end{array}$ & In vitro & $\begin{array}{c}\text { Scanner: Dental Wing, Straumann, Canada } \\
\text { Milling machine: Yena-Dent D30, Istanbul } \\
\text { Turkey }\end{array}$ & Zirconia blocks (Whitepeaks, Germany) & $\begin{array}{l}\text { All surface treatmentmethods (sandblasting with alumina particles, } \\
\text { Trico chemical silicacoating or Trico chemical silica coating } \\
\text { followed by silanization) increase tensile bond strength of zirconia } \\
\text { post and core. No significantdifferencewas found between } \\
\text { treatment methods. }\end{array}$ \\
\hline 29. & $\begin{array}{l}\text { Vinothkumar, } \\
\text { Kandaswamy, and } \\
\text { Chanana201147 }\end{array}$ & $\begin{array}{l}\text { CAD / CAM fabricated single-unit } \\
\text { all-ceramic post-core-crown } \\
\text { restoration }\end{array}$ & Case report & $\begin{array}{l}\text { Scanner: CEREC InLab 3D (SironaDental } \\
\text { Systems Inc, NY, USA) Milling machine: Not } \\
\text { specify }\end{array}$ & $\begin{array}{l}\text { Zirconia(IPS emax ZirCAD, Ivoclar, } \\
\text { Liechtenstein) }\end{array}$ & $\begin{array}{l}\text { Case report stated that the current availableCAD / CAM systems } \\
\text { are notprogrammed for the designing and manufacturing of } \\
\text { ceramic post and core This caseutilized polyvinylsiloxane } \\
\text { impression of the postspace (Dentsply, Germany) followed by } \\
\text { poured with CAM - Stone N(SiladentGermany) before opto- } \\
\text { electronic scanning and digital impressionswas done. }\end{array}$ \\
\hline 30. & $\begin{array}{l}\text { Liu, Dengetal. } \\
2010^{48}\end{array}$ & $\begin{array}{l}\text { Use of a CAD / CAM - fabricated } \\
\text { glass fiber postand core to restore } \\
\text { fractured anterior teeth: A clinical } \\
\text { report }\end{array}$ & Case report & $\begin{array}{l}\text { Scanner: SmartVision; Gimmafei Technology } \\
\text { Development Co, Ltd, Beijing, China Milling } \\
\text { machine: VMC 850s; She Hong Industrial Co, } \\
\text { Ltd, Taichung, Taiwan }\end{array}$ & $\begin{array}{l}\text { A prefabricated, composite resin- } \\
\text { wrapped, glass fiber block (Ouyaruikang } \\
\text { New Material Science and Technology, } \\
\text { China) }\end{array}$ & $\begin{array}{l}\text { Impression of post space wasmade using vinyl polysiloxane } \\
\text { (Flexitime; Germany) before being scanned and milled using a CAD } \\
\text { / CAM system which was designed specifically for dental } \\
\text { restorations and compatible with dental materials. Case } \\
\text { characteristic: No coronal portion of the tooth with 3-mm canal } \\
\text { opening. }\end{array}$ \\
\hline 31. & $\begin{array}{c}\text { Awad and } \\
\text { Marghalani } 2007^{49}\end{array}$ & $\begin{array}{l}\text { Fabrication of a custom-made } \\
\text { ceramic post and core using CAD - } \\
\text { CAM technology }\end{array}$ & & $\begin{array}{l}\text { Scanner and milling machine:yttrium- } \\
\text { tetragonal zirconium polycrystals (Y - TZP) } \\
\text { system (Cercon; DeguDent } \\
\text { GmbH; Hanau-Wolfgang, Germany). }\end{array}$ & Zirconia & $\begin{array}{l}\text { The pattern was scanned, milled, and sintered with zirconia. } \\
\text { Important information emphasized during preparation: No acute } \\
\text { angles werepresent atpost and core surfaces, The core-post } \\
\text { junction must have enough width to avoid fracture during milling, } \\
\text { Postmust has rounded internal line angles. }\end{array}$ \\
\hline
\end{tabular}

\begin{tabular}{|c|c|c|}
\hline \multirow{3}{*}{ Metal } & Commercial Name & Types \\
\hline & Coprabond K, WhitePeaks, Germany & Co-Cr block \\
\hline & * one study uses Ceramil wax block to fabricate metal (ni & ost and core) \\
\hline \multirow{8}{*}{ Ceramic } & VITA Zahnfabrik & Feldspathic ceramic \\
\hline & e.max CAD; Ivoclar Vivadent AG & Lithium disilicate reinforced glass-ceramic \\
\hline & Ambarino, Germany & Hybrid glass ceramic \\
\hline & InCoris; Dentsply Sirona & Zirconia \\
\hline & IPS e.max ZirCAD, Ivoclar, Liechtenstein & Zirconia \\
\hline & Zirconia blocks, Whitepeaks, Germany & Zirconia \\
\hline & Zirconia block, Amann Girrbach, Germany & Zirconia \\
\hline & Zirconia block Zirkonzahn, Switzerland & Zirconia \\
\hline \multirow{5}{*}{ Resin } & Paradigm MZ10, 3M ESPE, USA & Composite resin with ultrafine zirconia-silica ceramic \\
\hline & Lava Ultimate; $3 \mathrm{M}$ & Nanofill composite \\
\hline & Cerasmart, GC & Nanofill composite \\
\hline & Trilor, Bioloren & Glass reinforced fibre \\
\hline & Enamic; VITA Zahnfabrik & Polymer-infiltrated ceramic network (PICN) \\
\hline & e 2. Summary of Commercialize CAD / CAM I & ost and Core \\
\hline
\end{tabular}


Table 1 shows 31 studies related to CAD / CAM post and core from 2007 - 2020 (Tab.1). Analysis of these papers showed that there is an increase in research related to the topic for the past 3 years. This involved either case reports, clinical technique/workflow, in vitro studies, or finite element analysis studies. Apart from case report, most of the studies focused on in vitro studies with no in vivo study being found during the literatures search. This is most likely that in vitro studies allow the material to be studied safely, without subjecting humans or animals to the possible complication of the new materials. It is anticipated that future research will involve more on finite element analysis prior to in vivo studies as it offers flexibility in calculating stress pattern and distributions within post and core which are beneficial for development in designs and materials choice. ${ }^{50}$

\section{Material for Fabricating CAD / CAM Post and Core}

The ideal post and core materials should have similar physical and mechanical properties of dentin including modulus of elasticity, compressive strength, thermal expansion coefficient and optical properties.4,5,34 Nowadays, there are many CAD / CAM materials available in the market but most of the materials were mainly indicated for inlays, onlays, veneers, crown, bridges and implant abutment.51,52 Figure 3 shows the options available for chairside CAD / CAM restorative materials (Fig.3). The restorations that can be fabricated with a chairside system depends on the size and properties of the material block and size of the milling machine ${ }^{53}$ It was apparent that in recent year, chairside CAD / CAM materials either such as ceramic (zirconia, feldspathic and leucitereinforced ceramics or lithium disilicate and zirconium oxide and lithium silicate) and resin were often used in either in vitro studies and case reports apart from laboratory produced block. Table 2 summarizes to commercialize CAD / CAM materials used as post and core in the studies (Tab 2). For experimental CAD / CAM fiber post block, only da Costa, Freire et al. ${ }^{34}$ disclosed the composition of the materials (epoxy resin $25 \%$, epoxy hardener $25 \%$, glass fiber $70 \%$ ) while others mostly stated that it was made from epoxy polymer matrix. ${ }^{48,42,32}$ Research stated that recent resin CAD / CAM block offers better fracture toughness and resilience in comparison to ceramics due to the enhanced composition. ${ }^{28}$ Besides, it also has closer modulus of elasticity to dentin, has better marginal quality with no post-milling required. ${ }^{54}$ In addition, as the underlying core may affect the definitive restoration of ceramic crown, the tooth colour restoration of post and core such as ceramic and resin block can offer an advantage as compared to custom made metal post. Few studies also explore new experimental fibre-reinforced composite CAD / CAM blocks as options in fabricating the CAD / CAM post and core. ${ }^{10,32,36}$ Most of the failures observed in prefabricated fiber post and core was debonding, which is due to the difference in interface between two material ${ }^{55}$ This can be overcome using a CAD / CAM one-piece post and core where better adaptation can be achieved in the radicular area and create more favourable conditions for the retention of the post. Besides, the flexural properties of glass reinforced fiber is almost similar to dentin as compared to zirconia which are more rigid. ${ }^{42}$ Considering the idea of similar physical and mechanical properties of dentin, these new materials can be a good alternative for fabricating CAD / CAM post and core. However, due to their recent introduction to the market, longterm clinical studies on these materials are not available yet.

\section{Designing and Fabrication on CAD / CAM Post and Core}

\subsubsection{CAD /CAM System}

The post and core restoration fabricated by CAD / CAM technology can be achieved either by direct digitalization of the post space $56,57,22$ or an indirect digitalization using either impression of post space with a resin pattern or polyvinylsiloxane impression. ${ }^{8}$

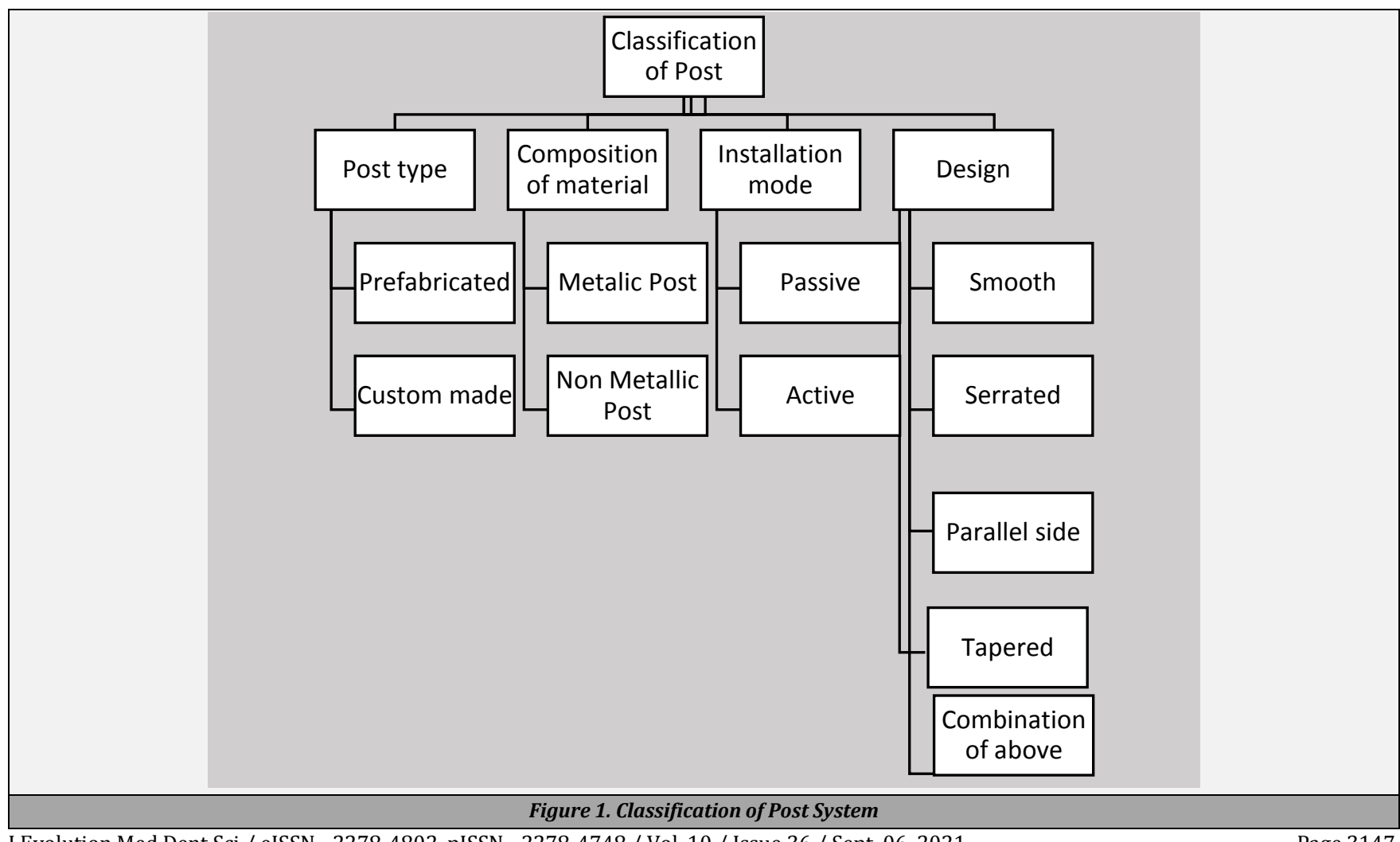



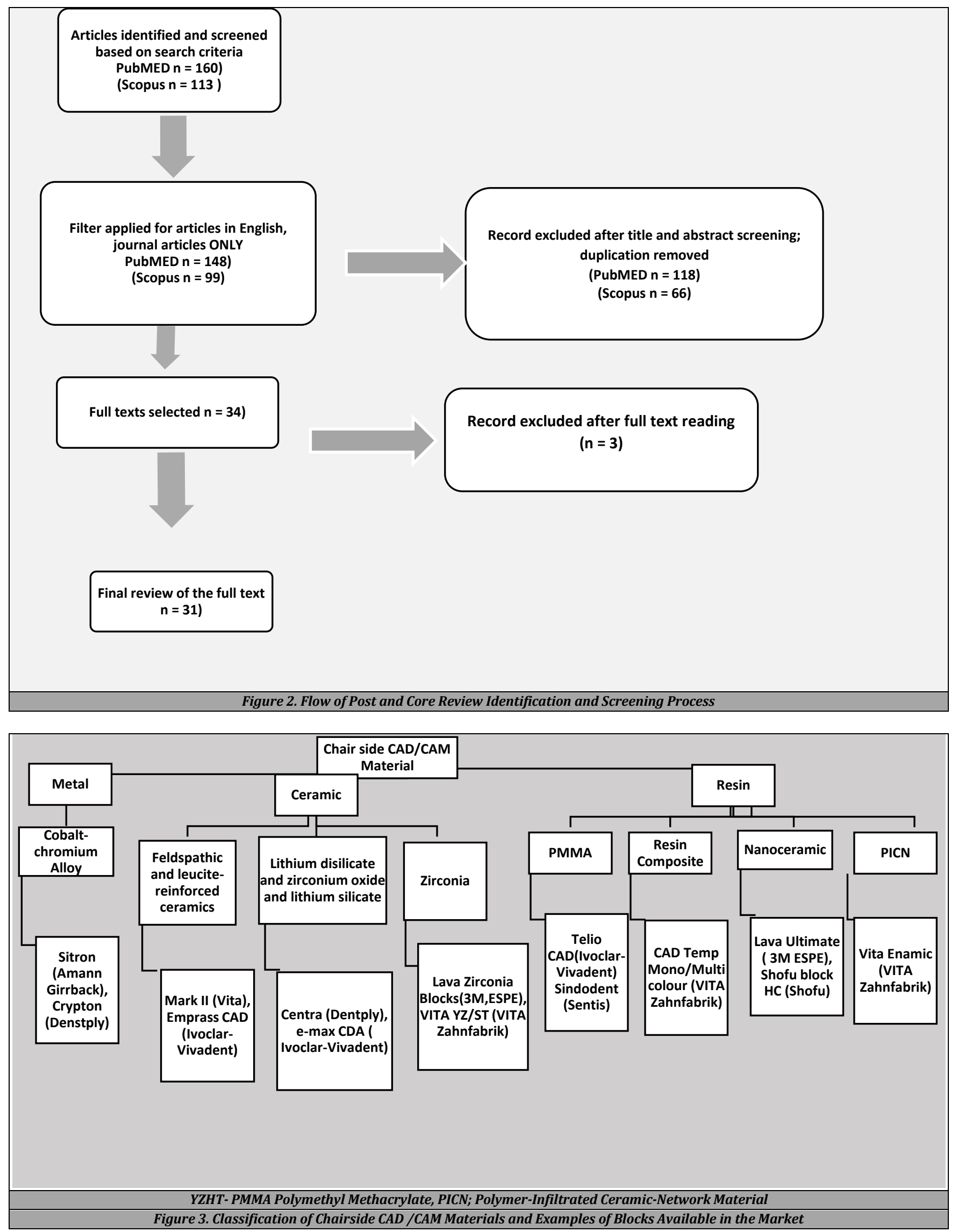

Table 1 illustrated the variety of CAD / CAM system used during the fabrication of post and core within last 13 years. (Tab. 1). There is increase in number and new systems of the intraoral scanners, milling machines, and other CAD / CAM equipment available on the market. Our review revealed that most studies conducted would either use CEREC (Dentsply
Sirona, York, PA), Trios, 3Shape (Copenhagen, Denmark), Dental Wings (Montreal, Canada) and few other systems. After scanning, the data would be processed using the particular CAD / CAM software to develop a digital 3D model of the post and core prior milling and sintering. ${ }^{10}$ Nowadays, there are many software available for the type and intended use of CAD 
/ CAM systems either clinical or laboratory. Through the latest technology, most of the software have become more user friendly to help the clinician with the design. However, the scanning and software available for market are focused on scanning of the extracoronal restoration. Although direct digitalization may simplify the clinical and laboratory procedure of fabrication of post and core, it can be difficult to detect narrow root channel in the case of post and core scanning. ${ }^{58}$ Intraoral camera of the CEREC system cannot scan lengths that are deeper than $10 \mathrm{~mm}$ of the post space hole. Most case reports and in vitro studies also reveal that the preparation of post length prior scanning is mainly around 9 mm length. ${ }^{28}$ The highest fracture strength reported was with $10 \mathrm{~mm}$ post length as compared to $5 \mathrm{~mm}$ post length ${ }^{59}$ while another study found that no statistically significant difference was noted between the $12 \mathrm{~mm}$ and $8 \mathrm{~mm}$ post lengths. ${ }^{60}$ Though it is well known that the success rate of endodontically treated teeth are higher with post length equal to two thirds of the root length, or atleast the same length as the crown height. ${ }^{61}$

Recently, 3Shape has developed special intraoral 3Shape scan posts ${ }^{\mathrm{TM}}$ where it can be used as chairside and for model scanning to facilitate and capture the precise depth of the post and core restorations. ${ }^{62}$ It comes with various shapes and sizes to support different post and core drill systems in the market. One in vitro study that compared the quality of post-space reading using an intraoral scanner and indirect digitalization of impression in post space found that the application of the intraoral scanner for the post-space readings are not reliable as compared to the indirect impression technique due to the incomplete post-space reading. ${ }^{57}$ Nevertheless, a more recent study comparing intraoral scanner (Trios, 3shape) and laboratory scanner (Imetric 1041, Courtenay, Switzerland) found that complete digital workflow exhibited better adaptation as compared to indirect digitalization with resin pattern or silicone impression as it introduced more variables. ${ }^{30}$

\section{CAM /CAM Milling Machine}

The choice of milling machine is depending on CAD / CAM material used and manufacturer recommendation. It is an unclear boundary between chairside digital manufacturing and laboratory-based CAD / CAM technologies. Some of the clinicians would prefer to send a scan file to any manufacturing site to produce in-office restoration, which others would prefer to do it in laboratory. ${ }^{53}$ Generally chairside milling unit consists 4 -axis mill $(3+1)$ which is perfectly adequate for most clinical applications, such as veneers, inlays, onlays, crowns, and fixed dental prostheses. However, for milling post and core, previous researches suggested that milling machine should be integrated with either 5-axis or more axes where it can rotate in additional axes and enable to mill more complex designs, even in present of undercuts. ${ }^{53,30}$ Besides, slower and low-stress milling machine was recommended to reduce vibrations, inaccuracy or failure of the machining process due to the nature and geometry of post and core.51 Additionally, simultaneous machining with extra-fine milling procedure is advisable to prevent post breakage. 30

\section{Advantages of CAD / CAM Post and Core}

The use of dental CAD / CAM-systems in combination with CAD / CAM materials allows the aesthetic demands of dental restorations to be achieved in one day. It can be an alternative to prefabricated and conventional custom-made casting methods as it can provides patients with "same-day" restorations. The advance of the CAD / CAM technology in the field of dentistry has brought the solution which it can reduce the waiting time to receive the prosthesis by reducing the number of clinical procedures involved in prosthesis fabrication. ${ }^{63}$ The use of direct digitalization was more efficient as compared to conventional technique, involved in making impressions. It can simplify the clinical procedure and it also helps in improving communication with patient as well as can act as powerful advertising and marketing tool. Endodontic teeth restored with post and core restorations produce stress concentrated at the coronal third of the root and at the interface between the core and good adaptation in the post space and structure can be achieved with the aid of CAD / CAM technology presenting the one-piece post and core entities. Potential separation of the core due to different modulus elasticity is unlikely to occur when it composed from the same material. Besides, it creates the monobloc effect as the post, core and crown act as single unit and declines the incidence of failure. The CAD / CAM technology produces a post and core that improves the fitting accuracy, fast and highquality prosthesis. The quality of the restoration is more consistent as compared to prefabricated post and core. It also helps to minimize the inaccuracies and provides standardization of prosthesis fabrication. ${ }^{10}$

\section{Future Direction of CAD / CAM Post and Core}

In early year, CAD / CAM systems were able to fabricate dental restoration limited to inlays, onlays, and single crowns only. With the current trend and advancement of technology on CAD / CAM systems, milling machine and other devices, there is almost no limit to the type of dental restoration that can be constructed using this technology. More and more clinical reports published stated that CAD / CAM post and core can be one of the promising treatment alternative in aesthetically compromised teeth with wide flared root canal. ${ }^{22}$ To date, most researches on CAD / CAM post and core were focused on the experimental in vitro laboratory studies.10,35 Within the limitation of the in vitro studies, they found that CAD / CAM post and core showed a good performance in fracture resistance and bond strength. Apart from finite element analysis study, future research of well-designed clinical trials would be valuable in assessing the success, survival and failure rate of CAD / CAM post and core. This can provide more evidence on the clinical performance and failure modes of CAD / CAM post and core on recent and different materials of choice. Apart from CAD / CAM, it is also expected that there would be an increase in research emphasis on threedimensional (3D) printing in fabrication and manufacturing process on post and core. 


\section{CONCLUSIONS}

Even though there is no consensus on the superiority of CAD / CAM custom made cast posts and cores when compared with prefabricated posts systems, a "one-piece" post and core can offer good adaptation in the post space and structure that lacks post and core interface. Designing and fabricating CAD / CAM post and core can be one of the alternative option apart from conventional post and core. However, the choice of material available for post and core should be taken with care as there is lack of clinical information and evidence on current material in fabricating the post and core.

Financial or other competing interests: Nor Faharina Abdul Hamid, Nurul Jannah Zulkefle, Tengku Fazrina Tengku Mohd Ariff, and Zuryati $\mathrm{Ab}$ Ghani received grants from Fundamental Research Grant Scheme for Research Acculturation of Early Career Researchers (FRGS RACER) 600 - IRMI /FRGS - RACER 5 /3 (020 /2019) outside the submitted work.

Disclosure forms provided by the authors are available with the full text of this article at jemds.com.

\section{REFERENCES}

[1] Cheung W. A review of the management of endodontically treated teeth. Post, core and the final restoration. J Am Dent Assoc 2005;136(5):611-9.

[2] Girotto LPS, Dotto L, Pereira GKR, et al. Restorative preferences and choices of dentists and students for restoring endodontically treated teeth: a systematic review of survey studies J Prosthet Dent 2020:S00223913(20)30407-8.

[3] Bhalla VK, Chockattu SJ, Srivastava S, et al. Decision making and restorative planning for adhesively restoring endodontically treated teeth: an update. Saudi Endodontic Journal 2020;10(3):181-6.

[4] Machado J, Almeida P, Fernandes S, et al. Currently used systems of dental posts for endodontic treatment. Procedia Structural Integrity 2017;5:27-33.

[5] Manhart J. Fiberglass reinforced composite endodontic posts. Endod Prac 2009;16:6-20.

[6] Bittner N, Hill T, Randi A. Evaluation of a one-piece milled zirconia post and core with different post-and-core systems: an in vitro study. J Prosthet Dent 2010;103(6):369-79.

[7] Santos-Filho PCF, Castro CG, Silva GR, et al. Effects of post system and length on the strain and fracture resistance of root filled bovine teeth. Int Endod J 2008;41(6):493-501.

[8] Soares LP, De Souza PG, Garcia C, et al. Designing a custom-made post and core using CAD/CAM technology's CEREC system. CJRDP 2014;7(3):40-8.

[9] Plasmans PJ, Visserman LG, Vrjiheof MM, et al. In vitro comparison of dowel and core techniques for endodontically treated molars. J Endod 1986;12(9):3827.

[10] Pang J, Feng C, Zhu X, et al. Fracture behaviors of maxillary central incisors with flared root canals restored with CAD/CAM integrated glass fiber post-and-core. Dent Mater J 2019;38(1):114-9.

[11] Bergman B, Lundquist P, Sjo U. et al. Restorative and endodontic results after treatment with cast posts and cores. J Prosthet Dent 1989;61(1):10-5.
[12] Creugers NH, Mentink AG, Käyser AF. An analysis of durability data on post and core restorations. J Dent 1993;21(5):281-4.

[13] Fraga RC, Chaves BT, Mello GS, et al. Fracture resistance of endodontically treated roots after restoration. J Oral Rehabil 1998;25(11):809-13.

[14] Martinez-Insua A, Da Silva L, Rilo B, et al. Comparison of the fracture resistances of pulpless teeth restored with a cast post and core or carbon-fiber post with a composite core. J Prosthet Dent 1998;80(5):527-32.

[15] Al-Omiri MK, Rayyan MR, Abu-Hammad O. Stress analysis of endodontically treated teeth restored with postretained crowns: a finite element analysis study. J Am Dent Assoc 2011;142(3):289-300.

[16] Khaledi AAR, Sheykhian S, Khodaei S. Evaluation of retention of two different cast post-core systems and fracture resistance of the restored teeth. J Dent (Shiraz) 2015;16(2):121-8.

[17] Akkayan B, Gülmez T. Resistance to fracture of endodontically treated teeth restored with different post systems. J Prosthet Dent 2002;87(4):431-7.

[18] Rosentritt M, Furer C, Behr M, et al. Comparison of an vitro fracture strength of metallic and tooth coloured posts and cores. J Oral Rehabil 2000;27(7):595-601.

[19] Meyenberg KH, Luthy H, Scharer P. Zirconia posts: a new all-ceramic concept for nonvital abutment teeth. J Esthet Restor Dent 1995;7(2):73-80.

[20] Perucelli F, Da Costa RG, De Souza EM, et al. Effect of halfdigital workflows on the adaptation of customized CADCAM composite post-and-cores. J Prosthet Dent 2020;S0022-3913(20)30463-7.

[21] Farah RFI, Aloraini AS, Al-Haj Ali SN. Fabrication of custom post-and-core using a directly fabricated silicone pattern and digital workflow. J Prosthodont 2020;29(7):631-5.

[22] Libonati A, Taranto VD, Gallusi G, et al. CAD/CAM customized glass fiber post and core with digital intraoral impression: a case report. Clin Cosmet Investig Dent 2020;12:17-24.

[23] De Andrade GS, Tribst JPM, De Olivera Dal Piva AM, et al. A study on stress distribution to cement layer and root dentin for post and cores made of CAD/CAM materials with different elasticity modulus in the absence of ferrule. J Clin Exp Dent 2019;11(1):e1-8.

[24] Eid RY, Koken S, Baba NZ, et al. Effect of fabrication technique and thermal cycling on the bond strength of CAD/CAM milled custom fit anatomical post and cores: an in vitro study. J Prosthodont 2019;28(8):898-905.

[25] Eid R, Azzam K, Skienhe H, et al. Influence of adaptation and adhesion on the retention of computer-aided design/computer-aided manufacturing glass fiber posts to root canal. J Contemp Dent Pract 2019;20(9):1003-8.

[26] Alkhatri R, Saleh ARM, Kheder W. Evaluating fracture resistance and failure modes of root filled teeth restored with CAD/CAM-fabricated post and core. Clin Cosmet Investig Dent 2019;11:349-55.

[27] Ahmet BSO, Egilmez F, Ergun G, et al. Surface treatment effects on bond strength of CAD/CAM fabricated posts to root canal dentin. Am J Dent 2019;32(3):113-7.

[28] Eid R, Juloski J, Ounsi H, et al. Fracture resistance and failure pattern of endodontically treated teeth restored with computer-aided design/computer-aided 
manufacturing post and cores: a pilot study. J Contemp Dent Pract 2019;20(1):56-63.

[29] Borzangy SS, Saker SM, Al-Zordk WA. Effect of restoration technique on resistance to fracture of endodontically treated anterior teeth with flared root canals. J Biomed Res 2019;33(2):131-8.

[30] Moustapha G, Alshwaimi E, Silwadi M, et al. Marginal and internal fit of CAD/CAM fiber post and cores. Int J Comput Dent 2019;22(1):45-53.

[31] Spina DRF, Da Costa RG, Correr GM, et al. Scanning of root canal impression for the fabrication of a resin CAD-CAMcustomized post-and-core. J Prosthet Dent 2018;120(2):242-5.

[32] Tsintsadze N, Juloski J, Carrabba $M$, et al. Effects of scanning technique on in vitro performance of CAD/CAMfabricated fiber posts. J Oral Sci 2018;60(2):262-8.

[33] Garcia PP, Da Costa RG, Garcia AV, et al. Effect of surface treatments on the bond strength of CAD/CAM fiberglass posts. J Clin Exp Dent 2018;10(6):e591-7.

[34] Da Costa RG, Freire A, De Morais ECC, et al. Effect of CAD/CAM glass fiber post-core on cement micromorphology and fracture resistance of endodontically treated roots. Am J Dent 2017;30(1):3-8.

[35] Gonzaga CC, Correr GM. CAD/CAM post-and-core using different esthetic materials: fracture resistance and bond strengths. Am J Dent 2017;30(6):299-304.

[36] Tsintsadze N, Juloski J, Carrabba M, et al. Performance of CAD/CAM fabricated fiber posts in oval-shaped root canals: an in vitro study. Am J Dent 2017;30(5):248-54.

[37] Bilgin MS, Erdem A, Dilber E, et al. Comparison of fracture resistance between cast, CAD/CAM milling and direct metal laser sintering metal post systems. J Prosthodont 2016;60(1):23-8.

[38] Gülnahar E, Soygun K, Bolayır G. The customized forming of the applied post-core system: case reports. J Dent Probl Solut 2016;3(1):31-4.

[39] Kalyoncuoğlu E, Ural C, Aydemir H, et al. Effect of 1-piece post and core fabrication techniques on fracture strength. J Appl Biomater Funct Mater 2015;13(3):253-8.

[40] Chen A, Feng X, Zhang Y, et al. Finite element analysis of stress distribution in four different endodontic post systems in a model canine. Biomed Mater Eng 2015;26(Suppl 1):S629-35.

[41] Chen A, Feng X, Zhang Y, et al. Finite element analysis to study the effects of using CAD/CAM glass-fiber post system in a severely damaged anterior tooth. Biomed Mater Eng 2015;26(Suppl 1):S519-25.

[42] Chen Z, Li Y, Deng X, et al. A novel computer-aided method to fabricate a custom one-piece glass fiber dowel-andcore based on digitized impression and crown preparation data. J Prosthodont 2014;23(4):276-83.

[43] Ozcan N, Sahin E. In vitro evaluation of the fracture strength of all-ceramic core materials on zirconium posts. Eur J Dent 2013;7(4):455-60.

[44] Marghalani TY, Hamed MT, Awad MA, et al. Threedimensional finite element analysis of custom-made ceramic dowel made using CAD/CAM technology. J Prosthodont 2012;21(6):440-50.

[45] Kumar R, Patil S. Forced orthodontic extrusion and use of CAD/CAM for reconstruction of grossly destructed crown: a multidisciplinary approach. J Conserv Dent 2012;15(2):191-5.
[46] Sipahi C, Toksoy F, Ayyildiz S, et al. Effect of physical and physicochemical surface treatment methods on the tensile strength of CAD/CAM-fabricated zirconia posts and cores luted to root canals. Int J Periodont Rest 2011;31(5):64-7.

[47] Vinothkumar TS, Kandaswamy D, Chanana P. CAD/CAM fabricated single-unit all-ceramic post-core-crown restoration. J Conserv Dent 2011;14(1):86-9.

[48] Liu P, Deng XL, Wang XZ. Use of a CAD/CAM-fabricated glass fiber post and core to restore fractured anterior teeth: a clinical report. J Prosthet Dent 2010;103(6):3303.

[49] Awad MA, Marghalani TY. Fabrication of a custom-made ceramic post and core using CAD-CAM technology. J Prosthet Dent 2007;98(2):161-2.

[50] Trivedi S. Finite element analysis: a boon to dentistry. J Oral Biol Craniofac Res 2014;4(3):200-3.

[51] Lambert H, Durand JC, Jacquot B, et al. Dental biomaterials for chairside CAD/CAM: state of the art. J Adv Prosthodont 2017;9(6):486-95.

[52] Fasbinder DJ. Materials for chairside CAD/CAM restorations. Compend Contin Educ Dent 2010;31(9):702-9.

[53] Blatz MB, Conejo J. The current state of chairside digital dentistry and materials. Dent Clin North Am 2019;63(2):175-97.

[54] Mainjot AK, Dupont NM, Oudkerk JC, et al. From artisanal to CAD-CAM blocks: state of the art of indirect composites. J Dent Res 2016;95(5):487-95.

[55] Ferrari M, Cagidiaco MC, Goracci C, et al. Long-term retrospective study of the clinical performance of fiber posts. Am J Dent 2007;20(5):287-93.

[56] Campanella V, Carosi P, Casella S, et al. Clinical fitting of a cast metal post and core obtained by means of an intraoral optical scanning (IOS) and digital workflow. J Biol Regul Homeost 2019;33(3 Suppl 1):43-50.

[57] Pinto A, Arcuri L, Carosi P, et al. In vitro evaluation of the post-space depth reading with an intraoral scanner (IOS) compared to a traditional silicon impression. Oral Implantol (Rome) 2017;10(4):360-8.

[58] Mangano F, Gandolfi A, Luongo G, et al. Intraoral scanners in dentistry: a review of the current literature. BMC Oral Health 2017;17(1):149.

[59] Jindal S, Jindal R, Mahajan S, et al. In vitro evaluation of the effect of post system and length on the fracture resistance of endodontically treated human anterior teeth. Clin Oral Investig 2012;16(6):1627-33.

[60] Cecchin D, Farina AP, Guerreiro CAM, et al. Fracture resistance of roots prosthetically restored with intraradicular posts of different lengths. J Oral Rehabil 2010;37(2):116-22.

[61] Braga NMA, Paulino SM, Alfredo E, et al. Removal resistance of glass-fiber and metallic cast posts with different lengths. J Oral Sci 2006;48(1):15-20.

[62] 3Shape releases CAD solution for post and core restorations. 3Shape 2013. [cited $2013 \quad 17$ July] https://www.3shape.com/en/press/2013/cad-solutionfor-post-and-core-restorations.

[63] Lee JH. Fabricating a custom zirconia post-and-core without a post-and-core pattern or a scan post. J Prosthet Dent 2018;120(2):186-9. 